\title{
Derivation of multivariate indices of milk composition, coagulation properties, and individual cheese yield in dairy sheep
}

\author{
M. G. Manca, ${ }^{*}$ J. Serdino, ${ }^{*}$ G. Gaspa, ${ }^{*}$ P. Urgeghe, ${ }^{*}$ I. Ibba,† M. Contu,† P. Fresi,‡ and N. P. P. Macciotta ${ }^{* 1}$ \\ *Dipartimento di Agraria, Università di Sassari, 07100 Sassari, Italy \\ †Associazione Regionale Allevatori della Sardegna, 09128 Cagliari, Italy \\ $\ddagger$ Associazione Nazionale della Pastorizia, 00161 Rome, Italy
}

\section{ABSTRACT}

Milk composition and its technological properties are traits of interest for the dairy sheep industry because almost all milk produced is processed into cheese. However, several variables define milk technological properties and a complex correlation pattern exists among them. In the present work, we measured milk composition, coagulation properties, and individual cheese yields in a sample of 991 Sarda breed ewes in 47 flocks. The work aimed to study the correlation pattern among measured variables and to obtain new synthetic indicators of milk composition and cheese-making properties. Multivariate factor analysis was carried out on individual measures of milk coagulation parameters; cheese yield; fat, protein, and lactose percentages; somatic cell score; casein percentage; $\mathrm{NaCl}$ content; $\mathrm{pH}$; and freezing point. Four factors that were able to explain about $76 \%$ of the original variance were extracted. They were clearly interpretable: the first was associated with composition and cheese yield, the second with udder health status, the third with coagulation, and the fourth with curd characteristics. Factor scores were then analyzed by using a mixed linear model that included the fixed effect of parity, lambing month, and lactation stage, and the random effect of flock-test date. The patterns of factor scores along lactation stages were coherent with their technical meaning. A relevant effect of flock-test date was detected, especially on the 2 factors related to milk coagulation properties. Results of the present study suggest the existence of a simpler latent structure that regulates relationships between variables defining milk composition and coagulation properties in sheep. Heritability estimates for the 4 extracted factors were from low to moderate, suggesting potential use of these new variables as breeding goals.

Received November 2, 2015.

Accepted March 2, 2016.

${ }^{1}$ Corresponding author: macciott@uniss.it
Key words: factor analysis, sheep milk, coagulation properties, cheese yield

\section{INTRODUCTION}

Dairy sheep farming is widespread in many regions of Europe, especially in the Mediterranean area, where about $63 \%$ of the world's sheep milk is produced (FAOSTAT, 2014). The most important producers are Greece $(699,500$ t/yr), Romania (651,912 t/yr), Spain $(552,517$ t/yr), and Italy $(406,177$ t/yr; FAOSTAT, 2014). The Italian dairy sheep stock consists of about 5,500,000 animals (FAO, 2014), 60\% of which are of the Sarda breed. The average gross milk production of the Sarda dairy industry is about 330,000 t/yr (Osservatorio Regionale per l'Agricoltura, 2012). All milk is destined to cheese production. In particular, 3 Protected Designation of Origin cheeses from Sarda sheep milk are currently manufactured in Italy: Pecorino Romano, which is largely exported to the United States (about 10,000 t/yr; ISMEA, 2013), Pecorino Sardo, and Fiore Sardo.

The breeding program of the Sarda breed includes 220,268 ewes (ICAR, 2014). Current selection goals are lactation milk yield and scrapie resistance. Fat and protein percentages and udder morphology are measured routinely only on first-lactation ewes, mainly to reduce costs of phenotype recording. However, there is interest in milk quality, especially on novel phenotypes related to nutritional characteristics, such as milk fatty acid composition (Carta et al., 2009) and cheese-making suitability.

Several variables contribute to the definition of technological properties of milk, and different phenotypes have been proposed to reliably characterize its cheesemaking ability. Micro-manufacturing experiments have been suggested as a tool to quantify individual cheese yield in sheep (Othmane et al., 2002a). This variable is of great interest even though its use in routine phenotype recording programs is problematic. Milk coagulation properties (MCP) are assessed measures of milk cheese-making aptitude (Bittante et al., 2012; Pretto 
et al., 2013). They have been suggested as breeding goals for dairy cattle (Ikonen et al., 2004; Bittante et al., 2012; Chessa et al., 2013). Coagulation properties are usually defined by 3 variables: rennet coagulation time (RCT, min), curd firming time $\left(\mathbf{k}_{\mathbf{2 0}}, \mathbf{m i n}\right)$, and curd firmness $\left(\mathbf{a}_{\mathbf{3 0}}, \mathbf{m m}\right)$. They are measured directly by mechanical and optical techniques (Bittante, 2011). Moreover, they can be estimated by mid-infrared reflectance spectroscopy (MIRS) of fresh milk by using appropriate calibration algorithms (Dal Zotto et al., 2008; Bittante, 2011).

Although most of literature on MCP deals with dairy cattle, some studies have been carried out on dairy sheep. In particular, effects of fat and protein contents, temperature, pH (Park, 2007), SCC (Nudda et al., 2001), milk protein polymorphism (Piredda et al., 1993), and parity (Pazzola et al., 2014) on MCP have been investigated. Moreover, environmental factors such as stage of lactation (Jaramillo et al., 2008), flocktest date (Pazzola et al., 2014), and lambing season (Martini et al., 2008) have been found to affect sheep milk renneting properties.

Some authors have pointed out that a complex correlation pattern exists between traits that contribute to define the technological properties of milk, resulting in difficulties in the elucidation of causal relationships among variables (Ikonen et al., 2004; Cecchinato et al., 2011; Bland et al., 2015). In the specific case of MCP, the high degree of correlation that exists among RCT, $\mathrm{k}_{20}$, and $\mathrm{a}_{30}$ represents a limitation for the use of these variables in the interpretation of the milk coagulation pattern (Bittante et al., 2015).

Multivariate statistics offers a set of methodologies for studying and dissecting complex correlation patterns. In particular, factor analysis has been used to study the correlation structure among milk compositional variables and MCP in Italian Brown Swiss cattle, allowing for the extraction of latent factors that were interpreted as indicators of milk composition, coagulation, acidity, and mammary gland health (Macciotta et al., 2012). Todaro et al. (2001) used factor analysis to study milk composition of ewes of the Valle del Belice breed and found 3 latent factors from 14 original variables, related to cheese yield, mastitis infection, and aptitude of milk for cheese making. In a further work on Girgentana goats, the same authors extracted 3 factors related to coagulation time, milk yield, and curd firmness (Todaro et al., 2005). Factor analysis was also used by Abilleira et al. (2010) to study relationships between milk composition, coagulation properties, and season of production in Latxa sheep.

The aim of the present work was to study the relationship pattern between milk composition, MCP, and experimental cheese yield in Sarda ewes by using multi- variate factor analysis. This approach was expected to generate new variables with potential technical meaning that could be used for management and breeding purposes.

\section{MATERIALS AND METHODS}

\section{Animals and Milk Sampling}

The study was carried out on 991 Sarda ewes in 47 flocks (about 18 ewes per herd) located in the 4 historical provinces of Sardinia, Italy. All the ewes involved in the experiment were officially recorded in the herd book of Sarda breed. The individual milk samples (1 per animal from the morning milking) were collected between April and July 2014. Preservative was added to all milk samples, stored at room temperature, and processed $24 \mathrm{~h}$ after collection. Chemical composition of milk (fat percentage, protein percentage, lactose percentage, $\mathrm{pH}$, urea, $\mathrm{NaCl}$ ) and cryoscopy index were determined by Fourier transform mid-infrared (FTMIR) spectroscopy equipment (MilkoScan, Foss Electric, Hillerød, Denmark). Calibration algorithms were developed according to FIL-IDF rules (ISO 9622:2013; IDF, 2013). Somatic cell count values (Fossomatic, Foss Electric) were also measured and converted to SCS by logarithm transformation as proposed by Ali and Shook (1980).

\section{Analysis of MCP}

The MCP were measured using a Formagraph (Foss Electric). Briefly, $10 \mathrm{~mL}$ of each individual sample was heated to $35^{\circ} \mathrm{C}$ before the addition of $200 \mu \mathrm{L}$ of rennet solution (Hansen Naturen 215, with $80 \pm 5 \%$ chymosin and $20 \pm 5 \%$ pepsin, Pacovis Amrein AG, Bern, Switzerland) diluted to $0.8 \%$ in distilled water, resulting in a final dosage of 0.034 international milk clotting units $(\mathbf{I M C U}) / \mathrm{mL}$. This analysis ended within $30 \mathrm{~min}$ after rennet addition and produced a diagram as reported by Bittante et al. (2012). The following coagulation traits were recorded: RCT (which describes the time in minutes from the addition of the enzyme to the beginning of the coagulation process), $\mathrm{k}_{20}$ (which describes the time in minutes needed to obtain a curd firmness of 20 $\mathrm{mm}$ ), and $\mathrm{a}_{30}$ (which describes the width in millimeters of the diagram at $30 \mathrm{~min}$ after the rennet addition).

\section{Individual Laboratory Cheese Yield Analysis}

The individual laboratory cheese yield (ILCY) was measured according to the method proposed by Othmane et al. (2002a) with some modifications. Raw milk samples were heated to $40^{\circ} \mathrm{C}$ and gently mixed by 
shaking; then, exactly $10 \mathrm{~g}$ was weighed into a test tube (15 mm interior diameter) and allowed to equilibrate for $10 \mathrm{~min}$ to $36^{\circ} \mathrm{C}$ in a water bath. The equipment used allowed us to process 12 tubes in the same session. Immediately before coagulation, a working solution (15 $\mathrm{IMCU} / \mathrm{mL}$ ) of rennet was prepared by diluting, with ultrapure water, a 1,000 IMCU $/ \mathrm{mL} 100 \%$ chymosin solution (Chy-Max M 1000, Hansen A/S, Hørsholm, Denmark).

A volume of $40 \mu \mathrm{L}$ of the work solution was added to the tubes to reach a final dose of $0.060 \mathrm{IMCU} / \mathrm{g}$. Then, the tubes were closed and rapidly inverted to ensure uniform distribution of the rennet and left undisturbed at $36^{\circ} \mathrm{C}$ in a water bath for $1 \mathrm{~h}$. The coagulum was then cut in the form of a cross and underwent centrifugation at $1,750 \times g$ for $15 \mathrm{~min}$ at $36^{\circ} \mathrm{C}$ to allow whey separation. The residual whey was removed after draining for 45 min with the test-tube facing downward. The ILCY was defined as the relative weight of the centrifuge residue on the original weighed milk and was expressed in weight percentage $(\% \mathrm{wt} / \mathrm{wt})$.

\section{Statistical Analysis}

The basic theoretical assumption of the factor model is that the total variance of a multivariate system can be partitioned into 2 components: one that is shared by all the variables (called communality) and another that is peculiar to each variable (called uniqueness). Consequently, each of $n$ original variables could be modeled as a linear combination of $p$ common factors that generates the communality between variables plus a residual specific (Morrison, 1976).

Multivariate factor analysis was carried out on the whole data set. Twelve variables were considered: RCT, $\mathrm{k}_{20}, \mathrm{a}_{30}$, ILCY, fat percentage (FP), protein percentage $(\mathbf{P P})$, lactose percentage (LAC), SCS, casein percentage (CAS), $\mathrm{NaCl}$ content $(\mathrm{NaCl}), \mathrm{pH}$, and freezing point. Analysis was carried out using PROC FACTOR of SAS (SAS Institute, 2008). A varimax orthogonal rotation was performed to improve the readability of factors in terms of biological and technical meaning and of relationships with the original variables.

The number of factors to be retained was assessed by examining the amount of variance explained by the extracted factors and their readability (Morrison, 1976). Factor meaning was assessed by visual inspection of patterns: a variable was considered significantly associated with a factor when its loading (i.e., the correlation coefficient between the variable and the extracted factor) was $\geq 0.60$ (Macciotta et al., 2012).

Individual factor scores calculated for each ewe were used as new phenotypes and analyzed using the following mixed linear model:

$$
\begin{array}{rl}
y_{i j k l m}=F & T D_{i}+L_{M O N T H_{j}}+D I M_{j} \\
& +P A R_{l}+e_{i j k l m},
\end{array}
$$

where $y$ is the score of the $p$ th factor of the $m$ th ewe; $F T D$ is the random effect of the $i$ th flock-test date $(66$ levels $), \sim N\left(0, \sigma_{F T D}^{2}\right) ; L M O N T H$ is the fixed effect of the $j$ th month of lambing (4 levels: January, February, November, December); DIM is the fixed effect of lactation stage $k$ ( 8 intervals of DIM of $30 \mathrm{~d}$, starting from parturition); $P A R$ is the fixed effect of the lth parity ( 8 levels: 1 to 7 and $>7$ ); and $e$ is the random residual, $\sim N\left(0, \sigma_{e}^{2}\right)$.

Average lactation curves corrected for other effects included in the model were obtained by plotting least squares means of the DIM effect against days in milk (Stanton et al., 1992).

To evaluate the possibility of using these new extracted variables as breeding goals for the genetic improvement of milk quality and cheese-making ability, their genetic background was investigated. Factor scores were analyzed with the following animal model:

$$
\begin{aligned}
y_{i j k l m n}=F T D_{i} & +L_{M O N T H_{j}}+D M_{j}+P A R_{l} \\
& +a_{m}+e_{i j k l m n}
\end{aligned}
$$

that had the same structure as model [1] plus the inclusion of the random additive effect $(a)$ of the $m$ th animal $N\left(0, \mathbf{A} \sigma_{A}^{2}\right)$, where $\mathbf{A}$ is the additive relationship matrix, $\sigma_{A}^{2}$ is the additive genetic variance. (Co)variance components were estimated using the VCE software (Groeneveld et al., 2010). A total of 5,671 known ancestors without records were tracked from the pedigree, up to 4 generations. Thus, 6,551 animals were included in the numerator relationship matrix. Heritability was calculated as $\sigma_{a}^{2} /\left(\sigma_{e}^{2}+\sigma_{a}^{2}+\sigma_{F T D}^{2}\right)$, where $\sigma_{e}^{2}$ and $\sigma_{F T D}^{2}$ are the residual and test-date variance, respectively.

\section{RESULTS}

\section{Factor Analysis}

In total, 111 milk samples did not coagulate within the 30-min period and were not considered in the analysis. The considered sample size was therefore 880 ewes. About $10 \%$ of milk samples from Finnish Ayrshire cattle are noncoagulating (Ikonen et al., 2004). Average chemical composition, MCP, and individual cheese yields are reported in Table 1. Values observed for fat, protein, and lactose percentages were in agreement with previous reports for the Sarda breed for both individual (Pazzola et al., 2014; Nudda et al., 2015) 
Table 1. Mean and standard deviation of milk composition, coagulation properties, and individual cheese yield

\begin{tabular}{lrr}
\hline Trait & Mean & SD \\
\hline Fat percentage & 6.00 & 1.38 \\
Protein percentage & 5.41 & 0.68 \\
Casein percentage & 4.20 & 0.55 \\
Lactose percentage & 4.83 & 0.42 \\
SCS & 4.31 & 2.03 \\
Freezing point $\left({ }^{\circ} \mathrm{C}\right)$ & 0.57 & 0.04 \\
pH & 6.55 & 0.24 \\
NaCl $(\mathrm{mg} / 100 \mathrm{~mL})$ & 139.08 & 33.19 \\
Individual cheese yield $(\%)$ & 35.22 & 8.21 \\
Rennet coagulation time (min) & 13.39 & 4.45 \\
Curd firming time (min) & 1.75 & 0.73 \\
Curd firmness $(\mathrm{mm})$ & 54.99 & 12.10 \\
\hline
\end{tabular}

and bulk tank milk data (Pirisi et al., 2000). The average SCS was similar to values previously observed in the Sarda breed by Mele et al. (2006) but higher than previous reports by Nudda et al. (2003, 2015).

As far as MCP are concerned, the average RCT was similar to values obtained for Sarda (Pirisi et al., 1999; Mele et al., 2006) and Spanish (Jaramillo et al., 2008; Abilleira et al., 2010; Rovai et al., 2015) sheep breeds, whereas it was markedly higher than in a recent report on Sarda ewes (Pazzola et al., 2014). Average values for $\mathrm{k}_{20}$ and $\mathrm{a}_{30}$ were similar to previous values observed in dairy sheep (Bittante et al., 2014; Pazzola et al., 2014). The mean for ILCY was larger than values reported by Othmane et al. (2002a) for Churra ewes but similar to that found by Corral et al. (2009) for Merino ewes.

A preliminary step in factor analysis is an assessment of the suitability of the data set to this statistical approach. The evaluation is made by comparing the Pearson $\left(\mathbf{r}_{\mathrm{PEAR}}\right)$ and partial $\left(\mathbf{r}_{\mathrm{PAR}}\right)$ correlations between the observed variables (Table 2). A marked decrease of $r_{\mathrm{PAR}}$ compared with $\mathrm{r}_{\mathrm{PEAR}}$ supports the factor hypothesis of an underlying latent structure that regulates correlations of the multivariate system under study. In the present study, such a decrease was observed for several pairs of variables (Table 2). The exceptions were some correlations involving lactose content, freezing point, and $\mathrm{NaCl}$ content: $\mathrm{r}_{\mathrm{PEAR}}$ and $\mathrm{r}_{\mathrm{PAR}}$ tended to increase and sometimes also changed in sign. A measure of the difference between values of $r_{P E A R}$ and $r_{P A R}$ is the Kaiser measure of sampling adequacy (MSA; Cerny and Kaiser, 1977). The value of MSA in this study was 0.57 , similar to those reported in previous studies for dairy cattle (Macciotta et al., 2012) and goats (Todaro et al., 2005).

Four factors were retained for further analysis according to the amount of variance explained and to their interpretation in terms of biological meaning and relationships with the original variables (Morrison, 1976). The 4 factors were able to explain about $76 \%$ of the original variance (Table 3). Their structure, after the varimax rotation, was simple to read. Each factor exhibited few large and many small loadings, and each variable had a large loading in only one factor and small loadings in the others, respectively. An exception was SCS, which did not reach the threshold of significance in any of the extracted factors, even though it exhibited similar moderate correlations (albeit with the opposite sign) with the second and third factors, respectively.

The first factor (which explained $25 \%$ of the original variance) was correlated mainly with fat, protein, and casein contents, and with ILCY. The milk of animals with higher scores for this factor is richer in main components and able to give higher cheese yields, as expected. This factor was named the "composition_yield" index. The second factor (about 20\% of the original variance explained) was positively associated with lactose percentage and freezing point and negatively

Table 2. Pearson (above the diagonal) and partial (under the diagonal) phenotypic correlations among milk composition traits and milk coagulation properties ${ }^{1,2}$

\begin{tabular}{|c|c|c|c|c|c|c|c|c|c|c|c|c|}
\hline & $\mathrm{RCT}$ & $a_{30}$ & $\mathrm{k}_{20}$ & ILCY & $\mathrm{FP}$ & $\mathrm{PP}$ & LAC & SCS & CAS & FRE & $\mathrm{pH}$ & $\mathrm{NaCl}$ \\
\hline $\mathrm{a}_{30}$ & -0.02 & & -0.70 & -0.30 & -0.17 & 0.02 & 0.25 & -0.23 & 0.03 & 0.19 & -0.15 & -0.23 \\
\hline $\mathrm{k}_{20}$ & 0.47 & -0.56 & & 0.28 & 0.09 & 0.00 & -0.31 & 0.34 & -0.01 & -0.20 & 0.36 & 0.36 \\
\hline FP & -0.08 & -0.05 & -0.06 & 0.45 & & 0.46 & -0.49 & 0.26 & 0.48 & 0.09 & -0.06 & 0.17 \\
\hline PP & -0.08 & -0.03 & -0.01 & 0.05 & -0.26 & & -0.43 & 0.25 & 0.99 & 0.14 & -0.05 & 0.13 \\
\hline LAC & 0.03 & 0.03 & -0.07 & 0.26 & -0.72 & -0.02 & & -0.41 & -0.39 & 0.40 & 0.04 & -0.84 \\
\hline FRE & -0.02 & 0.03 & 0.02 & -0.17 & 0.57 & -0.00 & 0.77 & -0.11 & 0.08 & & 0.03 & -0.26 \\
\hline $\mathrm{pH}$ & 0.55 & 0.14 & -0.03 & 0.14 & 0.07 & 0.02 & 0.15 & 0.09 & -0.04 & -0.08 & & 0.09 \\
\hline $\mathrm{NaCl}$ & 0.08 & 0.06 & -0.01 & 0.23 & -0.58 & 0.20 & -0.92 & 0.21 & -0.30 & 0.66 & 0.09 & \\
\hline
\end{tabular}

${ }^{1}$ Standard errors ranged from 0.010 to 0.029 and from 0.013 to 0.029 for Pearson and partial correlations, respectively.

${ }^{2} \mathrm{RCT}=$ rennet coagulation time; $\mathrm{a}_{30}=$ curd firmness; $\mathrm{k}_{20}=$ curd firming time; ILCY = individual laboratory cheese yield; $\mathrm{FP}=$ fat percentage; $\mathrm{PP}=$ protein percentage $\mathrm{LAC}=$ lactose percentage $\mathrm{CAS}=$ casein percentage $\mathrm{FRE}=$ freezing point $; \mathrm{NaCl}=$ sodium chloride percentage. 
associated with $\mathrm{NaCl}$. Lactose and $\mathrm{NaCl}$ contents are 2 indicators of the integrity of mammary gland cells and they tend to decrease and increase, respectively, in ewes affected by clinical mastitis (Pulina and Nudda, 2004; Martí De Olives et al., 2013). Freezing point is an indicator of the osmotic equilibrium in milk and blood (Henno et al., 2008). Larger scores of this factor were therefore associated with higher lactose and lower $\mathrm{NaCl}$ contents, respectively; that is, with a better health status of the mammary gland. This factor was named the "udder health" index. It is interesting to note that SCS showed its second largest loading in this factor, even though it was below the threshold of 0.6.

The third factor presented large $(>0.60)$ and positive loadings with $\mathrm{pH}$ and $\mathrm{RCT}$. An increase of scores for this factor indicated a worsening of milk renneting performance, and it was therefore named the "coagulation" index. It is interesting to note that SCS was close to the threshold of significance in this factor. The fourth factor was correlated positively with $\mathrm{a}_{30}$ and negatively with $\mathrm{k}_{20}$; therefore, it was considered an index of "curd" characteristics.

As expected, variables expressed different communalities (Table 3). Largest values were for lactose, protein, and casein percentages, and the lowest were for SCS and freezing point. These findings are in agreement with a previous report for dairy cattle (Macciotta et al., 2012). However, values of communality for MCP were markedly larger than those reported in dairy goats (Todaro et al., 2005).

\section{Mixed Model Analysis}

The composition_yield factor was affected only by stage of lactation $(P<0.001)$. Its pattern mimicked the curve of fat and protein contents (Figure 1a). An increase of ILCY across lactation stages was observed by Othmane et al. (2002a). The contribution of flock-test date (FTD) to the phenotypic variance, calculated as $\sigma_{F T D}^{2} /\left(\sigma_{F T D}^{2}+\sigma_{e}^{2}\right)$, was 0.22 .

None of the considered effects in model [1] significantly affected the udder health factor. However, the lactation stage effect was close to significance $(P=$ 0.07). A tendency of udder health scores to decrease (i.e., a worsening of mammary health status) was observed as lactation proceeded (Figure 1b). The pattern was similar to the standard shape of the lactation curve, in agreement with a previous report in cattle for a factor with similar meaning (Macciotta et al., 2012). The contribution of FTD to the phenotypic variance was 0.19 .

The coagulation factor was affected by parity $(P=$ $0.009)$ and stage of lactation $(P=0.046)$. In particular, values tended to increase from first to later parities (Table 4), indicating a worsening of MCP with the age of animals. A significant effect of parity on RCT has been reported for Sarda sheep (Pazzola et al., 2014). A decrease of coagulation factor scores was noted across lactation stages, especially in late lactation (Figure 1c). The contribution of FTD to the phenotypic variance was 0.25 .

Finally, scores of the curd factor were affected by lambing month $(P=0.039)$ and stage of lactation $(P$ $=0.008)$. In particular, ewes lambing in November had the highest least-squares means for the scores of this factor (Table 5); that is, their milk showed the best curd characteristics. The lactation pattern (Figure 1d) showed a worsening of curd characteristics at the end of lactation. The contribution of FTD to the phenotypic variance was 0.46 .

\section{Genetic Parameters}

Heritabilities of the 4 extracted factors showed low to moderate values (Table 6). The largest value of $h^{2}$ was estimated for the udder health scores. It was

Table 3. Rotated factor pattern and variable communality

\begin{tabular}{|c|c|c|c|c|c|}
\hline Trait & $\begin{array}{c}\text { Factor 1: } \\
\text { Composition_yield }\end{array}$ & $\begin{array}{l}\text { Factor 2: } \\
\text { Udder health }\end{array}$ & $\begin{array}{c}\text { Factor 3: } \\
\text { Coagulation }\end{array}$ & $\begin{array}{l}\text { Factor } 4: \\
\quad \text { Curd }\end{array}$ & Communality \\
\hline Fat percentage & 0.72 & -0.12 & -0.18 & -0.34 & 0.68 \\
\hline Protein percentage & 0.91 & -0.09 & 0.12 & 0.15 & 0.88 \\
\hline Lactose percentage & -0.42 & 0.87 & -0.02 & 0.14 & 0.95 \\
\hline SCS & 0.29 & -0.42 & 0.47 & -0.09 & 0.49 \\
\hline Freezing point & 0.28 & 0.64 & 0.08 & 0.14 & 0.52 \\
\hline Individual cheese yield & 0.62 & 0.03 & 0.17 & -0.48 & 0.64 \\
\hline Rennet coagulation time & 0.20 & -0.14 & 0.82 & -0.30 & 0.83 \\
\hline Curd firming time & -0.04 & -0.26 & 0.49 & -0.70 & 0.80 \\
\hline Curd firmness & 0.01 & 0.16 & -0.15 & 0.87 & 0.82 \\
\hline Variance explained (\%) & 25 & 19 & 17 & 15 & \\
\hline
\end{tabular}




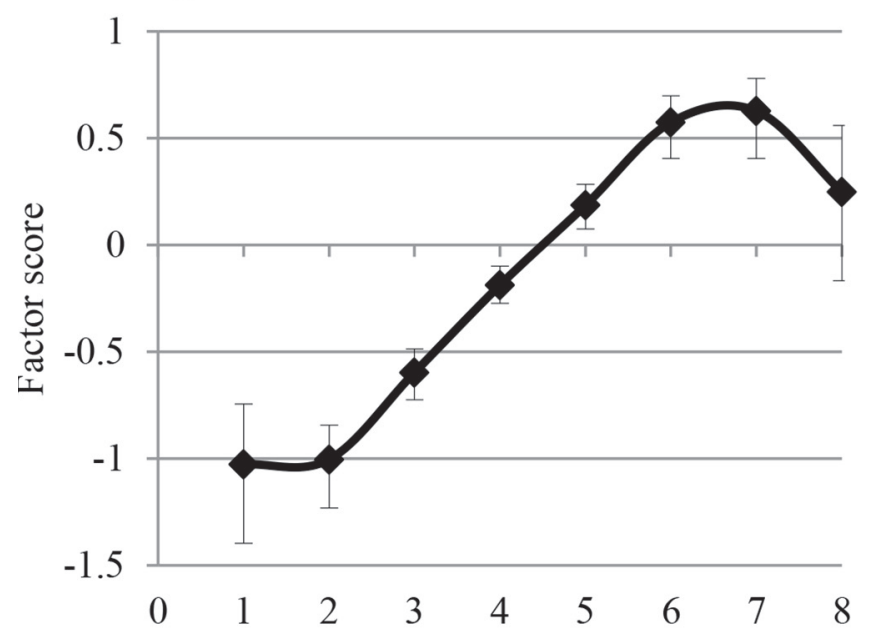

c

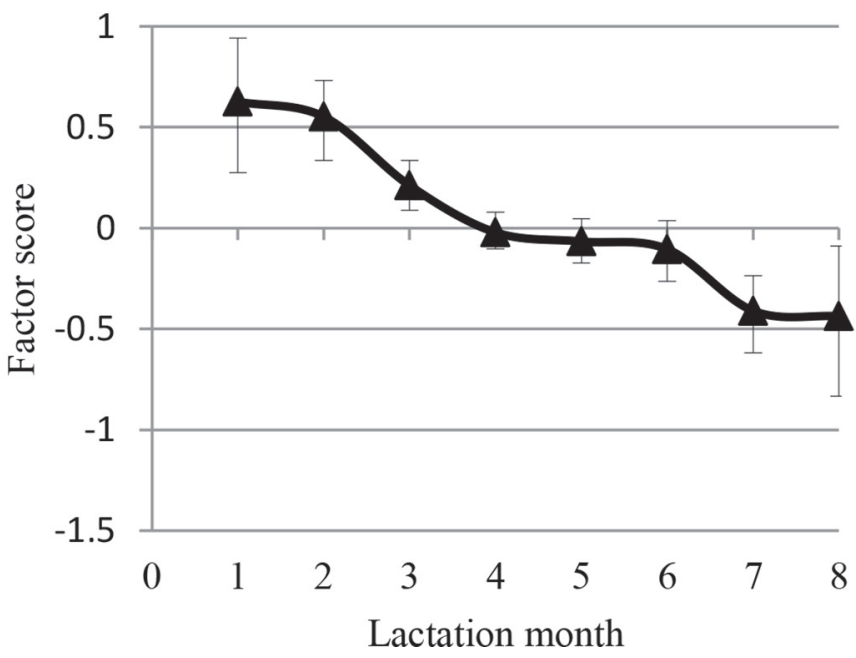

b

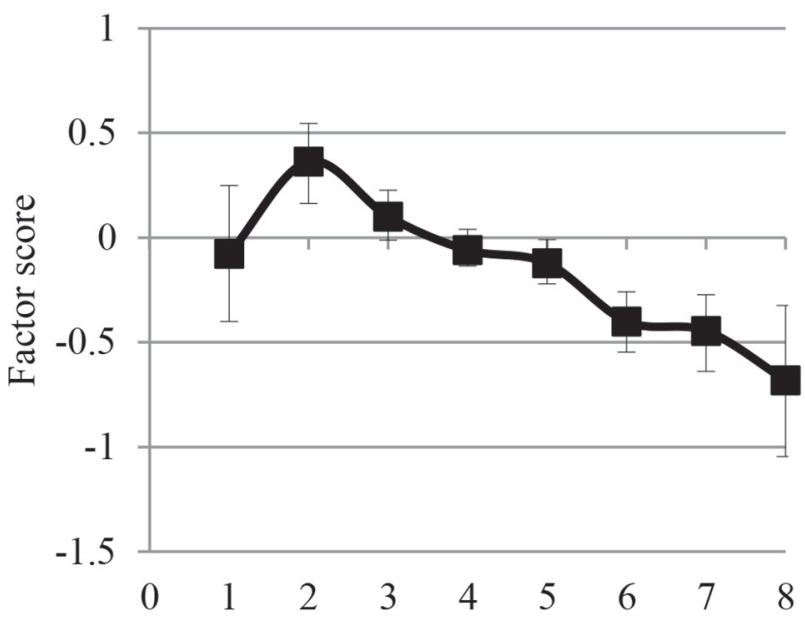

d

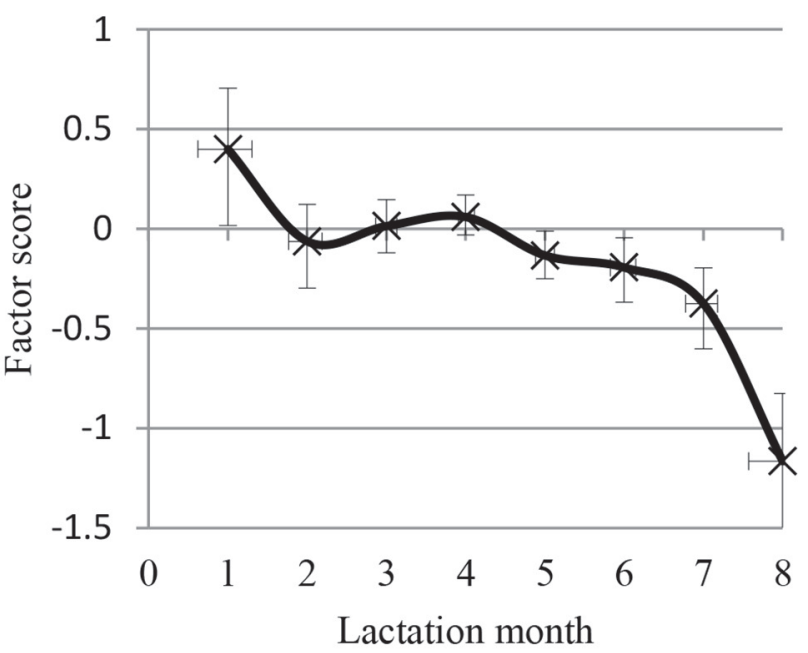

Figure 1. Pattern of the extracted common factor scores throughout lactation: (a) composition_yield; (b) udder health; (c) coagulation; and (d) curd. Plotted values are least squares means of the DIM factor of model [1]. Error bars are standard errors of the means.

Table 4. Least squares means and standard errors of the coagulation factor scores for different levels of parity estimated in the mixed model analysis

\begin{tabular}{lccc}
\hline Parity & $\begin{array}{c}\text { No. of } \\
\text { ewes }\end{array}$ & LSM & SE \\
\hline First & 172 & $-0.3014^{\mathrm{a}}$ & 0.1252 \\
Second & 113 & $-0.1747^{\mathrm{a}}$ & 0.1182 \\
Third & 138 & $0.0506^{\mathrm{ab}}$ & 0.1140 \\
Fourth & 155 & $0.1010^{\mathrm{ab}}$ & 0.1161 \\
Fifth & 105 & $0.0363^{\mathrm{ab}}$ & 0.1263 \\
Sixth & 81 & $0.1816^{\mathrm{ab}}$ & 0.1335 \\
Seventh & 59 & $0.2988^{\mathrm{b}}$ & 0.1468 \\
Eighth or greater & 57 & $0.1577^{\mathrm{ab}}$ & 0.1509 \\
\hline
\end{tabular}

a,b Means within columns with different superscripts differ (Tukeyadjusted $P<0.05)$. markedly larger than a previous estimate for a factor of similar meaning in dairy cattle (Macciotta et al., 2012). However, high heritability values for lactose content, which exhibited high loading in the udder health factor

Table 5. Least squares means and standard errors of the curd factor for different months of lambing estimated in the mixed model analysis

\begin{tabular}{lcc}
\hline Month of lambing & LSM & SE \\
\hline January & $-0.2304^{\mathrm{ab}}$ & 0.1344 \\
February & $-0.4704^{\mathrm{ab}}$ & 0.1878 \\
November & $0.09233^{\mathrm{a}}$ & 0.1244 \\
December & $-0.1214^{\mathrm{b}}$ & 0.1178 \\
\hline
\end{tabular}

${ }^{\mathrm{a}, \mathrm{b}}$ Means within columns with different superscripts differ (Tukeyadjusted $P<0.05)$. 
Table 6. Variance components and heritability estimates (standard errors in parentheses) for the 4 extracted factors $^{1}$

\begin{tabular}{lccccc}
\hline Factor & $\sigma_{a}^{2}$ & $\sigma_{F T D}^{2}$ & $\sigma_{e}^{2}$ & $r_{F T D}^{2}$ & $h^{2}$ \\
\hline Composition yield & 0.130 & 0.142 & 0.451 & $0.196(0.039)$ & $0.180(0.100)$ \\
Udder health & 0.363 & 0.162 & 0.464 & $0.168(0.042)$ & $0.378(0.119)$ \\
Coagulation & 0.042 & 0.226 & 0.683 & $0.247(0.045)$ & $0.046(0.070)$ \\
Curd & 0.138 & 0.434 & 0.410 & $0.442(0.053)$ & $0.140(0.081)$ \\
\hline
\end{tabular}

${ }^{1}$ Where $\sigma_{a}^{2}=$ additive genetic variance; $\sigma_{F T D}^{2}=$ flock-test date variance; $\sigma_{e}^{2}=$ residual variance; $r_{F T D}^{2}=$ contribution of the flock-test date variance to the total variance $\left[\sigma_{F T D}^{2} /\left(\sigma_{F T D}^{2}+\sigma_{a}^{2}+\sigma_{e}^{2}\right)\right]$.

of the present study, have been estimated in Danish Holstein and Jerseys cattle (Poulsen et al., 2015). The composition_yield factor showed an $h^{2}$ of about 0.20 , larger than the value estimated for ILCY in Churra dairy ewes but similar to that of protein and casein percentages estimated in the same study (Othmane et al., 2002c). Moreover, this value was similar to results obtained for individual cheese yield in Italian Simmental cattle (Cecchinato et al., 2015). The $h^{2}$ value estimated for the coagulation factor was very low (about 0.05), smaller than values usually reported for RCT (Bittante et al., 2012) but close to estimates reported for $\mathrm{pH}$ (Cecchinato et al., 2011; Bittante et al., 2012), a variable that is highly associated with this factor. The $h^{2}$ value of the curd factor was similar to that reported for $\mathrm{a}_{30}$ in cattle (Cassandro et al., 2008; Cecchinato et al., 2011). The contribution of FTD variance to the total phenotypic variance confirmed its relevant influence on all extracted factors, especially for the curd factor, with values similar to those obtained with the phenotypic model [1].

\section{DISCUSSION}

\section{Factor Analysis}

As noted by many authors, large variability in results can be observed between studies that report correlations between milk compositional and rheological traits. Values obtained in the present study (Table 2) agree in general with some previous reports for dairy species. For example, the correlation pattern between MCP was in agreement with studies in sheep (Pazzola et al., 2014) and cattle (Cassandro et al., 2008; Poulsen et al., 2015). On the other hand, weak relationships between MCP and milk composition were highlighted. These results confirm previous findings in cattle (Ikonen et al., 2004) and goats (Todaro et al., 2005), whereas they are not in agreement with reports by Auldist et al. (2004) in cattle and by Jaramillo et al. (2008) in sheep, which found moderate correlations (about -0.45) between curd firmness and fat and protein percentages. This disagreement between studies can be partly ascribed to a sampling effect. In many cases, as in the current work, one sample per animal is considered and great variability in experimental conditions between studies might be observed. On the other hand, a relevant role is played by the statistics used. Pearson correlations do not adequately represent causal relationships between variables (de la Fuente et al., 2004). Partial correlations, whose calculation is a fundamental preliminary step in factor analysis, help to elucidate the direct causal relationships between pairs of variables by removing the quota due to other variables. In the case of the present study, for example, the moderate positive correlation between RCT and SCS measured by $r_{\text {PEAR }}$ decreased markedly when $r_{P A R}$ is considered (Table 2). A similar result, albeit at the genetic level, was observed by Tiezzi et al. (2015); that study, aimed at clarifying possible causal relationships between milk composition and MCP, did not find any relationships between additive variations of RCT and SCS. The above-mentioned results and considerations seem to validate the suitability of the theoretical assumption of the factor model; that is, the existence of a simpler structure with few unobservable variables that controls the correlation structure among milk compositional and technological properties.

Multivariate factor analysis confirmed its ability in analyzing complex correlation patterns. In particular, factor analysis was able to extract, from 11 traits, 4 new variables able to represent a relevant quota of the original variance, with clear technical meaning and moderate to high values of heritability. Factor interpretation confirmed some previous reports in sheep, cattle, and goats (Todaro et al., 2005; Macciotta et al., 2012), even though some differences were apparent.

A factor related to MCP was obtained by performing multivariate factor analysis on milk composition and coagulation properties in cattle (Macciotta et al., 2012). However, in the present study the 2 basic components of MCP - coagulation and curd characteristics - were represented by different factors (coagulation and curd factors). A similar result was obtained in work on bulk milk of Latxa sheep (Abilleira et al., 2010) and on individual data of Girgentana goats (Todaro et al., 2005). 
The availability of 2 different and uncorrelated indicators of MCP could represent an advantage in studies of milk coagulation patterns that are hampered by the high degree of correlation between the traditional RCT, $\mathrm{a}_{30}$ and $\mathrm{k}_{20}$ (Bittante et al., 2015). A further peculiarity of the coagulation factor in the current study was its association with $\mathrm{pH}$, a variable strongly related to the coagulation process (Albenzio et al., 2004; Bonfatti et al., 2011; Martí De Olives et al., 2015), in agreement with previous reports on dairy sheep (Abilleira et al., 2010) and goats (Todaro et al., 2005). The substantial independence of MCP from the composition traits SCS and casein content was also observed by Tiezzi et al. (2015) in cattle. Those authors concluded that selection for RCT should be performed directly on the measured variable and not on the correlated traits as milk components.

An interesting result of the present study was the association of individual cheese yield to the composition_yield factor and not to the coagulation or curd factors. These findings seems to suggest a substantial independence of cheese yield from the coagulation process. Large correlations between individual cheese yield and milk fat content have been reported in dairy sheep (Othmane et al., 2002b; Jaramillo et al., 2008). Results of the present study are in agreement with the work of Bonfatti et al. (2014), which did not find any relationship between variation in MCP and laboratory cheese yield. On the other hand, Pretto et al. (2013) found a moderate correlation between MCP and Grana Padano cheese yield measured under field conditions in cheese plants. Differences in the experimental conditions (species, bulk or individual milk, laboratory vs. plant cheese making) could explain the different results. Values of ILCY measured in the present study were markedly larger than the industrial yield of Pecorino Romano cheese reported for Sarda ewes, which averaged 17.30\% (Pirisi et al., 2002). Such differences could be explained by the peculiarities of the micro-manufacturing experiments; that is, the small amount of milk processed and the use of forced draining (Othmane et al., 2002a). In any case, a correlation of 0.44 was found between ILCY values obtained in the present study and the theoretical cheese yields for Pecorino Romano predicted from milk composition using the equation proposed by Pirisi et al. (1994) (cheese yield $=1.747 \times$ protein content +1.272 $\times$ fat content). This equation was estimated using data from 34 industrial cheese-making processes $(5,000 \mathrm{~L}$ each) of Pecorino Romano and Pecorino Sardo.

If the 3 factors related to milk composition, coagulation, and curd characteristics have an interesting role in ranking animals for management and breeding purposes, the udder health factor is undoubtedly of relevant interest. In dairy sheep, as in other dairy spe- cies, diseases of the mammary gland, and in particular mastitis, have a large economic impact on farm profitability (Riggio et al., 2009). The udder health factor was associated with osmotic components of milk but not (perhaps surprisingly) with SCS, as observed in a factor of similar meaning in dairy cattle (Macciotta et al., 2012). The relationships between SCS and mastitis have also been assessed in dairy sheep (Cuccuru et al., 2011; Rovai et al., 2015). However, studies on dairy sheep also highlighted the relevant role of noninfectious factors in the variation of SCS (Arias et al., 2012). In the present paper, SCS did not reach the threshold of 0.60 for the loading in any of the extracted factors (the largest value, 0.47 , was on coagulation). Moreover, it did not show a large correlation with any of the considered variables; the largest $\mathrm{r}_{\mathrm{PEAR}}$ were with $\mathrm{RCT}$ and lactose (about 0.40 and -0.40 , respectively) but they decreased markedly in absolute value as $\mathrm{r}_{\mathrm{PAR}}$ (Table 2 ). The results obtained here, for correlations involving both SCS and its absence in factor patterns, are similar to those reported in sheep (Jaramillo et al., 2008) and goats (Todaro et al., 2005).

\section{Mixed Model Analysis and Heritability Estimates}

Mixed model analysis of individual factor scores highlighted a relevant effect of management and environmental conditions on all 4 factors, particularly on those related to MCP. It is worth mentioning that FTD accounted for about $45 \%$ of the total variance of the curd factor. Previous reports on Sarda and Spanish sheep breeds have underlined relevant seasonal and management effects on MCP (Abilleira et al., 2010; Pazzola et al., 2014), confirming reports in cattle (De Marchi et al., 2007). The other seasonal effect included in the model (i.e., month of lambing) showed a significant effect $(P<0.05)$ only on the curd factor. The better values for the scores of this factor for ewes lambing in November compared with December were in agreement with results of Sevi et al. (2004), which, in a study carried out on bulk tank milk, reported higher $\mathrm{a}_{30}$ and lower $\mathrm{k}_{20}$ for autumn compared with winter lambings. Those authors explained this result as an interaction between seasonal factors and stage of lactation. Similar results were obtained in a study on Massese ewes (Martini et al., 2008).

As expected, we detected an effect of lactation stage on both coagulation and curd factors. The lactation pattern for curd factor scores (Figure 1d) highlighted a worsening of curd characteristics in late lactation, in agreement with previous reports in sheep (Albenzio et al., 2004; Sevi et al., 2004; Jaramillo et al., 2008). In dairy cattle, the worst curd characteristics are often observed in mid lactation (Ikonen et al., 2004; Cipolat- 
Gotet et al., 2012; Penasa et al., 2014). The behavior of the coagulation factor (Figure 1c) was rather unexpected. Its scores tended to decrease during lactation, indicating a reduction of $\mathrm{RCT}$ as lactation proceeded. An increase of RCT with lactation stage has been observed in cattle (Ikonen et al., 2004) and in sheep (Jaramillo et al., 2008). On the other hand, Pazzola et al. (2014) in Sarda sheep reported a less-defined lactation pattern of RCT and found the shortest RCT for mid-lactation ewes. As previously reported, the strict seasonality of productive cycle for ewes farmed in Mediterranean countries often results in an interaction between stage of lactation and season of production. Sarda primiparous ewes lamb at the end of the winter, whereas older parities have lambings in fall to early winter. Most of sheep are dried off between June and July (Macciotta et al., 1999); therefore, when temperatures begin to increase (May), ewes are in mid to late lactation. Sevi et al. (2004) reported an increase of RCT during lactation for winter lambings but no difference for autumn lambings. Moreover, Sitzia et al. (2015), in their review, noted that some experiments did not find any difference in MCP between lactation stages. In fact, stage of lactation and diet quality had confounding effects in the farming system of sheep. An improvement of MCP in Sarda sheep in late lactation was obtained when animals were fed a balanced diet instead of the usual grazing on stubbles (Pulina et al., 1993). Moreover, Auldist et al. (2010) reported no negative effects of extended lactation on milk composition and cheese-making properties.

The stronger effect of parity on the coagulation factor confirms previous results on Sarda sheep that underlined a lower RCT of first-lambing ewes compared with older animals (Pazzola et al., 2014). Lower RCT for primiparous cattle were reported by several authors (Tyrisevä et al., 2003; Penasa et al., 2014). Other studies on cattle did not find any effect of parity on MCP (Ikonen et al., 2004; Bittante et al., 2015). Sevi et al. (2000) observed an improvement of $\mathrm{k}_{20}$ and $\mathrm{a}_{30}$ as the number of lactations increased in Comisana ewes but no significant differences in RCT.

All of the extracted factors except coagulation exhibited genetic variability. Of particular interest was the moderately high value of heritability obtained for the udder health factor. The use of the extracted factors as selection goals for breeding purposes would obviously increase costs and complexity of the selection program. However, equipment currently used for measuring milk composition is based on FT-MIR technology. The mid-infrared spectrum could be used to predict MCP (Chessa et al., 2013) and ILCY (Manca et al., 2015) with reasonable accuracy. Thus, the economic effort needed to enlarge the size of the population subjected to milk quality recording could be at least partly balanced by the ability to predict additional traits (MCP and ILCY) that could be used to calculate factor scores.

\section{CONCLUSIONS}

Results of the present study confirm the usefulness of the multivariate factor analysis as a tool for dissecting complex correlation patterns. Similarly to observations in cattle, a simple structure was able to explain the correlation pattern between measured variables. The 4 extracted factors - composition yield, udder health, coagulation, and curd - showed a well-defined technical meaning. They represent useful indicators of milk characteristics that could be used for management and breeding purposes.

\section{ACKNOWLEDGMENTS}

This research was supported by the Regional Government of Sardinia (Grant no. CRP 61608 "Il latte Ovino della Sardegna.") The authors thank the Provincial Breeders Farmers Associations (AIPA) of Cagliari, Nuoro, Sassari, and Oristano (Italy) for their support in sample collection; the laboratory of Associazione Regionale Allevatori della Sardegna (Oristano, Italy) for performing milk composition analysis; the Italian Associations of Animal Breeders (AIA) and of Sheep Breeders (ASSONAPA) for providing pedigree information. The authors also acknowledge Chr. Hansen (Hoersholm, Denmark) for providing the rennet used for the analysis.

\section{REFERENCES}

Abilleira, E., M. Virto, A. I. Nájera, J. Salmerón, M. Albisu, F. J. Pérez-Elortondo, J. C. Ruiz de Gordoa, M. de Renobales, and L. J. R. Barron. 2010. Effects of seasonal changes in feeding management under part-time grazing on the evolution of the composition and coagulation properties of raw milk from ewes. J. Dairy Sci. 93:3902-3909.

Albenzio, M., M. Caroprese, A. Santillo, R. Marino, L. Taibi, and A. Sevi. 2004. Effects of somatic cell count and stage of lactation on the plasmin activity and cheese-making properties of ewe milk. J. Dairy Sci. 87:533-542.

Ali, A. K. A., and G. E. Shook. 1980. An optimum transformation for somatic cell concentration in milk. J. Dairy Sci. 63:487-490.

Arias, R., B. Oliete, M. Ramón, C. Arias, R. Gallego, V. Montoro, C. Gonzalo, and M. D. Pérez-Guzmán. 2012. Long-term study of environmental effects on test-day somatic cell count and milk yield in Manchega sheep. Small Rumin. Res. 106:92-97.

Auldist, M. J., C. Grainger, A. V. Houlihan, J. J. Mayes, and R. P. W. Williams. 2010. Composition, coagulation properties, and cheesemaking potential of milk from cows undergoing extended lactations in a pasture-based dairying system. J. Dairy Sci. 93:1401-1411.

Auldist, M. J., K. A. Johnston, N. J. White, W. P. Fitzsimons, and M. J. Boland. 2004. A comparison of the composition, coagulation characteristics and cheese making capacity of milk from Friesian and Jersey dairy cows. J. Dairy Res. 71:51-57. 
Bittante, G. 2011. Modeling rennet coagulation time and curd firmness of milk. J. Dairy Sci. 94:5821-5832.

Bittante, G., C. Cipolat-Gotet, F. Malchiodi, E. Sturaro, F. Tagliapietra, S. Schiavon, and A. Cecchinato. 2015. Effect of dairy farming system, herd, season, parity and days in milk on modeling of coagulation, curd firming and syneresis of bovine milk. J. Dairy Sci. 98:2759-2774.

Bittante, G., E. Pellattiero, F. Malchiodi, C. Cipolat-Gotet, M. Pazzola, G. M. Vacca, S. Schiavon, and A. Cecchinato. 2014. Quality traits and modelling of coagulation, curd firming and syneresis of sheep milk of Alpine breeds fed diets supplemented with rumen protected conjugated fatty acid. J. Dairy Sci. 97:4018-4028.

Bittante, G., M. Penasa, and A. Cecchinato. 2012. Invited review: Genetics and modeling of milk coagulation properties. J. Dairy Sci. 95:6843-6870.

Bland, J. H., A. S. Grandison, and C. C. Fagan. 2015. Evaluation of milk compositional variables on coagulation properties using partial least squares. J. Dairy Res. 82:8-14.

Bonfatti, V., A. Cecchinato, L. Gallo, A. Blasco, and P. Carnier. 2011. Genetic analysis of detailed milk protein composition and coagulation properties in Simmental cattle. J. Dairy Sci. 94:5183-5193.

Bonfatti, V., M. Tuzzato, G. Chiarot, and P. Carnier. 2014. Variation in milk coagulation properties does not affect cheese yield and composition of model cheese. Int. Dairy J. 39:139-145.

Carta, A., S. Casu, and S. Salaris. 2009. Invited review: Current state of genetic improvement in dairy sheep. J. Dairy Sci. 92:5814-5833.

Cassandro, M., A. Comin, M. Ojala, R. Dal Zotto, M. De Marchi, L. Gallo, P. Carnier, and G. Bittante. 2008. Genetic parameters of milk coagulation properties and their relationships with milk yield and quality traits in Italian Holstein cows. J. Dairy Sci. 91:371376.

Cecchinato, A., C. Cipolat-Gotet, A. Ferragina, A. Albera, and G. Bittante. 2015. Genetic analyses of cheese yield and nutrient recovery or whey loss traits predicted using Fourier-transform infrared spectroscopy of samples collected during milk recording on Holstein, Brown Swiss and Simmental dairy cows. J. Dairy Sci. 98:4914-4927.

Cecchinato, A., M. Penasa, M. De Marchi, L. Gallo, G. Bittante, and P. Carnier. 2011. Genetic parameters of coagulation properties, milk yield, quality, and acidity estimated using coagulating and non coagulating milk information in Brown Swiss and HolsteinFriesian cows. J. Dairy Sci. 94:4205-4213.

Cerny, B. A., and H. F. Kaiser. 1977. A study of a measure of sampling adequacy for factor-analytic correlation matrices. Multivariate Behav. Res. 12:43-47.

Chessa, S., O. Bulgari, R. Rizzi, L. Calamari, and A. M. Caroli. 2013 Genetic analysis of milk clotting aptitude in the Italian HolsteinFriesian. Ital. J. Anim. Sci. 12(Suppl. 1):38.

Cipolat-Gotet, C., A. Cecchinato, M. De Marchi, M. Penasa, and G. Bittante. 2012. Comparison between mechanical and near-infrared methods for assessing coagulation properties of bovine milk. J. Dairy Sci. 95:6806-6819.

Corral, J. M., M. I. Cebrián, and J. Á. P. Peñas. 2009. Asociación del rendimiento quesero individual en laboratorio con la composición de la leche de la raza merina. Pages 568-570 in Proc. XXXIX Jornadas de Estudio: XIII Jornadas sobre producción animal, Zaragoza, Spain

Cuccuru, C., M. Meloni, E. Sala, L. Scaccabarozzi, C. Locatelli, P. Moroni, and V. Bronzo. 2011. Effects of intramammary infections on somatic cell score and milk yield in Sarda sheep. N. Z. Vet. J. 59:128-131.

Dal Zotto, R., M. De Marchi, A. Cecchinato, M. Penasa, M. Cassandro, P. Carnier, L. Gallo, and G. Bittante. 2008. Reproducibility and repeatability of measures of milk coagulation properties and predictive ability of mid-infrared reflectance spectroscopy. J. Dairy Sci. 91:4103-4112.

de la Fuente, A., N. Bing, I. Hoeschele, and P. Mendes. 2004. Discovery of meaningful associations in genomic data using partial correlation coefficients. Bioinformatics 20:3565-3574.
De Marchi, M., R. Dal Zotto, M. Cassandro, and G. Bittante. 2007. Milk coagulation ability of five dairy cattle breeds. J. Dairy Sci 90:3986-3992.

FAO. 2014. Food and Agriculture Organization of the United Nations, http://faostat3.fao.org/faostat-gateway/go/to/home/E. FAO, Rome, Italy.

FAOSTAT (Food and Agriculture Organization of the United Nations Statistics Division). 2014. Statistical Database of the Food and Agriculture Organization of the United Nations. http://faostat3. fao.org/faostat-gateway/go/to/home/E

Groeneveld, E., M. Kovac, and N. Mielenz. 2010. VCE User's Guide and Reference Manual Version 6.0. Institute of Farm Animal Genetics, Friedrich Loeffler Institute, Neustadt, Germany.

Henno, M., M. Ots, I. Joudu, T. Kaart, and O. Kärt. 2008. Factors affecting the freezing point stability of milk from individual cows. Int. Dairy J. 18:210-215.

ICAR (International Committee for Animal Recording). 2014. Dairy sheep milk survey online database. ICAR, Rome, Italy. Accessed Feb. 2015. http://www.survey-icar.org/sheep_survey4/.

IDF. 2013. International Dairy Federation (FIL-IDF). ISO 9622:2013. IDF 141:2013 (International Dairy Federation, Brussels, Belgium.).

Ikonen, T., S. Morri, A.-M. Tyrisevä, O. Ruottinen, and M. Ojala 2004. Genetic and phenotypic correlations between milk coagulation properties, milk production traits, somatic cell count, casein content, and pH of milk. J. Dairy Sci. 87:458-467.

ISMEA (Istituto di Servizi per il Mercato Agricolo Alimentare). 2013 Osservatorio economico ISMEA-LAORE Sardegna: Latte e formaggi ovini. I trimestre 2013. Rome, Italy.

Jaramillo, D. P., A. Zamora, B. Guamis, M. Rodrìguez, and A. J. Trujillo. 2008. Cheesemaking aptitude of two Spanish dairy ewe breeds: Changes during lactation and relationship between physico-chemical and technological properties. Small Rumin. Res. 78:48-55.

Macciotta, N. P. P., A. Cappio-Borlino, and G. Pulina. 1999. Analysis and environmental effects on test day milk yields of Sarda dairy ewes. J. Dairy Sci. 82:2212-2217.

Macciotta, N. P. P., A. Cecchinato, M. Mele, and G. Bittante. 2012 Use of multivariate factor analysis to define new indicator variables for milk composition and coagulation properties in Brown Swiss cows. J. Dairy Sci. 95:7346-7354.

Manca, M. G., J. Serdino, M. Cellesi, P. Urgeghe, I. Ibba, M. Contu, and N. P. P. Macciotta. 2015. Use of partial least squares regression to predict individual milk coagulation properties and cheese yield from Fourier transform infrared spectra in Sarda dairy sheep. J. Dairy Sci. 98(Suppl. 2):801. (Abstr.)

Martí De Olives, A., J. R. Díaz, M. P. Molina, and C. Peris. 2013 Quantification of milk yield and composition change as affected by subclinical mastitis in the short and the long term along the current lactation in sheep. J. Dairy Sci. 96:7698-7708.

Martini, M., M. Mele, C. Scolozzi, and F. Salari. 2008. Cheese making aptitude and the chemical and nutritional characteristics of milk from Massese ewes. Ital. J. Anim. Sci. 7:419-437.

Mele, M., A. Buccioni, F. Petacchi, A. Serra, S. Banni, M. Antongiovanni, and P. Secchiari. 2006. Effect of forage/concentrate ratio and soybean oil supplementation on milk yield, and composition from Sarda ewes. Anim. Res. 55:273-285.

Morrison, F. 1976. Multivariate Statistical Methods. McGraw-Hill, New York, NY.

Nudda, A., F. Correddu, A. Marzano, G. Battacone, P. Nicolussi, P. Bonelli, and G. Pulina. 2015. Effects of diets containing grape seed, linseed, or both on milk production traits, liver and kidney activities, and immunity of lactating dairy ewes. J. Dairy Sci. 98:1157-1166

Nudda, A., M. Feligini, G. Battacone, N. P. P. Macciotta, and G. Pulina. 2003. Effects of lactation stage, parity, beta-lactoglobulin genotype and milk SCC on whey protein composition in Sarda dairy ewes. Ital. J. Anim. Sci. 2:29-39.

Nudda, A., M. Feligini, G. Battacone, P. Murgia, and G. Pulina. 2001 Relationship between somatic cells count, whey protein and coagulation properties in sheep milk. Pages 511-513 in Proc. 14th Natl. Congr. ASPA, Firenze, Italy. 
Osservatorio Regionale per l'Agricoltura. 2012. La filiera ovicaprina in Sardegna. http://www.sardegnaagricoltura.it/ documenti/14_43_20131220133546.pdf.

Othmane, M. H., J. A. Carriedo, L. F. de la Fuente Crespo, and F. San Primitivo. 2002a. An individual laboratory cheese-making method for selection in dairy ewes. Small Rumin. Res. 45:67-73.

Othmane, M. H., J. A. Carriedo, F. San Primitivo, and L. F. De La Fuente. 2002b. Genetic parameters for lactation traits of milking ewes: Protein content and composition, fat, somatic cells and individual laboratory cheese yield. Genet. Sel. Evol. 34:581-596.

Othmane, M. H., L. F. De La Fuente, J. A. Carriedo, and F. San Primitivo. 2002c. Heritability and genetic correlations of test day milk yield and composition, individual laboratory cheese yield, and somatic cell count for dairy ewes. J. Dairy Sci. 85:2692-2698.

Park, Y. W. 2007. Rheological characteristics of goat and sheep milk. Small Rumin. Res. 68:73-87.

Pazzola, M., M. L. Dettori, C. Cipolat-Gotet, A. Cecchinato, G. Bittante, and G. M. Vacca. 2014. Phenotypic factors affecting coagulation properties of milk from Sarda ewes. J. Dairy Sci. 97:72477257.

Penasa, M., F. Tiezzi, A. Sturaro, M. Cassandro, and M. De Marchi 2014. A comparison of the predicted coagulation characteristics and composition of milk from multi-breed herds of Holstein-Friesian, Brown Swiss and Simmental cows. Int. Dairy J. 35:6-10.

Piredda, G., C. M. Papoff, R. Sanna, and R. L. Campus. 1993. Influenza del genotipo della a-s1 caseina ovina sulle caratteristiche chimico-fisiche e lattodinamometriche del latte. Sci. Tecn. Latt. Cas. 44:135-143

Pirisi, A., A. Murgia, and M. F. Scintu. 1994. Estimate of Pecorino Romano and Pecorino Sardo cheese yield from the protein and fat contents in sheep milk. Sci. Tecn. Latt. Cas. 48:229-240.

Pirisi, A., G. Piredda, and A. Carta. 2002. Resa di trasformazione del latte ovino: Applicabilità alla produzione industriale di un'equazione ricavata mediante microcaseificazioni. Page 246 in Proc. XV Natl. Congr. Società Italiana di Patologia e di Allevamento degli Ovini e dei Caprini, Chia - Cagliari, Italy.

Pirisi, A., G. Piredda, M. Corona, M. Pes, S. Pintus, and A. Ledda. 2000. Influence of somatic cell count on ewe's milk composition, cheese yield and cheese quality. Pages 47-59 in Proc. Great Lakes Dairy Sheep Conference. D. L. Thomas and S. Porter, ed. University of Madison, Madison, WI.

Pirisi, A., G. Piredda, C. M. Papoff, R. Di Salvo, S. Pintus, G. Garro, P. Ferranti, and L. Chianese. 1999. Effects of sheep alpha s1-casein $\mathrm{CC}, \mathrm{CD}$ and DD genotypes on milk composition and cheesemaking properties. J. Dairy Res. 66:409-419.

Poulsen, N. A., A. J. Buitenhuis, and L. B. Larsen. 2015. Phenotypic and genetic associations of milk traits with milk coagulation properties. J. Dairy Sci. 98:2079-2087.
Pretto, D., M. De Marchi, M. Penasa, and M. Cassandro. 2013. Effect of milk composition and coagulation traits on Grana Padano cheese yield under field conditions. J. Dairy Res. 80:1-5.

Pulina, G., and A. Nudda. 2004. Milk production. Pages 1-12 in Dairy Sheep Nutrition. G. Pulina, ed. CABI Publishing, New York, NY.

Pulina, G., A. Serra, N. P. P. Macciotta, and A. Nudda. 1993. La produzione continua di latte nella specie ovina in ambiente mediterraneo. Pages 353-356 in Proc. 10th Natl. Congr. Associazione Scientifica di Produzione Animale, Bologna, Italy.

Riggio, V., D. O. Maizon, B. Portolano, H. Bovenhuis, and J. A. M. van Arendonk. 2009. Effect of somatic cell count level on functional longevity in Valle del Belice dairy sheep assessed using survival analysis. J. Dairy Sci. 92:6160-6166.

Rovai, M., N. Rusek, G. Caja, J. Saldo, and G. Leitner. 2015. Effect of subclinical intramammary infection on milk quality in dairy sheep: I. Fresh-soft cheese produced from milk of uninfected and infected glands and from their blends. Small Rumin. Res. 125:127-136.

SAS Institute. 2008. SAS/STAT version 9.2. SAS Inst. Inc., Cary, NC

Sevi, A., M. Albenzio, R. Marino, A. Santillo, and A. Muscio. 2004. Effects of lambing season and stage of lactation on ewe milk quality. Small Rumin. Res. 51:251-259.

Sevi, A., L. Taibi, M. Albenzio, A. Muscio, and S. Dell'Aquila. 2000. Effect of parity on milk yield, composition, somatic cell count, renneting parameters and bacteria counts of Comisana ewes. Small Rumin. Res. 37:99-107.

Sitzia, M., A. Bonanno, M. Todaro, A. Cannas, A. S. Atzori, A. H D. Francesconi, and M. Trabalza-Marinucci. 2015. Feeding and management techniques to favour summer sheep milk and cheese production in the Mediterranean environment. Small Rumin. Res. 126:43-58.

Stanton, T. L., L. R. Jones, R. W. Everett, and S. D. Kachman. 1992. Estimating milk, fat, and protein lactation curves with a test day model. J. Dairy Sci. 75:1691-1700.

Tiezzi, F., B. D. Valente, M. Cassandro, and C. Maltecca. 2015. Causal relationships between milk quality and coagulation properties in Italian Holstein-Friesian dairy cattle. Genet. Sel. Evol. 47:45.

Todaro, M., M. L. Scatassa, M. L. Alicata, G. Leto, and S. Caracappa. 2001. The study of sheep milk composition by multivariate analysis. Pages 514-516 in Proc. 14th Natl. Congr. Italian Association of Animal Production (Associazione Scientifica di Produzione Animale).

Todaro, M., M. L. Scatassa, and P. Giaccone. 2005. Multivariate factor analysis of Girgentana goat milk composition. Ital. J. Anim. Sci. 4:403-410.

Tyrisevä, A. M., T. Ikonen, and M. Ojala. 2003. Repeatability estimates for milk coagulation traits and non-coagulation of milk in Finnish Ayrshire cows. J. Dairy Res. 70:91-98. 